\title{
An Overview of International Laws and Vietnamese Laws to Prevent and Compensate for Damage Caused by Offshore Oil Pollution
}

\author{
Tran Cong Thiet, PhD Student \\ Faculty of Law and Administration, University of Warsaw, Poland
}

Doi: 10.19044/elp.v7no3a3 URL:http://dx.doi.org/10.19044/elp.v7no3a3

\begin{abstract}
Pollution caused by offshore oil can cause severe damage and have lasting effects. It is recognized that preventing, treating, and compensating for damage caused by offshore oil pollution is a matter of great concern to all countries. As a result, international laws and regulations on the prevention and compensation of oil pollution have been promulgated one after another. Vietnam is a large maritime country that has been improving its own policies and laws on preventing, combating, and demanding compensation for damage caused by oil pollution, while studying international law on prevention and compensation of damage as a guideline. These improvements to pollution laws and policies are urgent because of the prevalence of and damage done by offshore oil. This study, therefore, focuses on the major international treaties to prevent, control, and compensate for damage caused by offshore oil pollution. Vietnam's policy formation and legislative process is particularly relevant in this area. Arguments to support Vietnam's policy formulation and legislative process is particularly important in joining the international treaties of Vietnam (International Convention Relating to Intervention on the High Seas in Cases of Oil Pollution Casualties, 1969, 1996).
\end{abstract}

Keywords: Marine Pollution, Civil Liability, Oil Pollution Damage.

\section{Introduction}

The protection of the marine environment is one of the issues that the international community pays special attention to because the sea plays a significant role in human life. Marine pollution is one of the most ominous disasters of environmental destruction. The sea is very susceptible to pollution, and the causes of pollution include various sources such as the mainland, activities of boats, oil exploitation, natural leaks, radiation, etc. It can be said that the largest and most dangerous source of pollution is shipped operations, especially tankers. In the world, from 1967 up to now, there have been many big oil spills. This has resulted to severe damage to the marine environment as 
well as economic damage to humans. When the sea is polluted, it will significantly affect the lives of people, affect all the creatures under the sea, and significantly impact the entire operation of seaports and the maritime industry worldwide. This is an activity considered to be the backbone of international trade today. The immediate and long-term damage to marine environment pollution and the losses that people directly suffer from include maritime, fishing, aquaculture, agriculture, fishery, tourism, etc. This is huge and requires a lot of time, wealth, and effort to prevent, limit, and overcome the marine environment as well as calculate damages for adequate compensation.

Vietnam is a coastal state whose territorial waters are three times larger than the land area, and the coast is longer than $3260 \mathrm{~km}$. Vietnam's sea is located on the arterial sea transport route connecting the Pacific - Indian Ocean, Europe - Asia, and Middle East - Asia. Five of the ten most extensive trade routes in the world are related to Vietnam's seas. This is considered the second busiest international transport route in the world. Every day, there are about 150-200 ships of all kinds going to the East Sea, and about 50\% are shipped with a tonnage of over 5,000 tons. Also, more than $10 \%$ are shipped with a tonnage of 30,000 tons or more. Therefore, this has led to the need for the study of marine pollution caused by oil and the study of the laws' provisions. Combating oil pollution from ships has been and is still an issue that many scholars in the countries of the world are concerned about. It is both a matter of urgent theory and practice today, and this is also an urgent issue that needs to be addressed. Therefore, understanding the provisions of international law plays an essential role in the development and improvement of Vietnamese law.

\section{The State of World Oil Pollution}

In modern history, humans have witnessed large-scale oil spills, which have had serious consequences for the marine environment. From 1967 to 2010, some typical oil pollution cases in the world are as follows (Staff, 2017):

The following list includes major oil spills since 1967. The circumstances surrounding the spill, amount of oil spilled, and the attendant environmental damage is also given.

March 18th, 1967, Cornwall, Eng.: Torrey Canyon ran aground, spilling 38 million gallons of crude oil off the Scilly Islands.

December 15th, 1976, Buzzards Bay, Mass.: Argo Merchant ran aground and broke apart southeast of Nantucket Island, spilling its entire cargo of 7.7 million gallons of fuel oil.

April, 1977, North Sea: blowout of well in Ekofisk oil field leaked 81 million gallons. 
March 16th, 1978, off Portsall, France: wrecked supertanker Amoco Cadiz spilled 68 million gallons, causing widespread environmental damage over $100 \mathrm{mi}$ of Brittany coast.

June 3rd, 1979, Gulf of Mexico: exploratory oil well Ixtoc 1 blew out, spilling an estimated 140 million gallons of crude oil into the open sea. Although it is one of the largest known oil spills, it had a low environmental impact.

July 19th, Tobago: the Atlantic Empress and the Aegean Captain collided, spilling 46 million gallons of crude. While being towed, the Atlantic Empress spilled an additional 41 million gallons off Barbados on August 2nd.

March 30th, 1980, Stavanger, Norway: floating hotel in North Sea collapsed, killing 123 oil workers.

February 4th, 1983, Persian Gulf, Iran: Nowruz Field platform spilled 80 million gallons of oil. August 6th, Cape Town, South Africa: the Spanish tanker Castillo de Bellver caught fire, spilling 78 million gallons of oil off the coast.

July 6th, 1988, North Sea off Scotland: 166 workers killed in explosion and fire on Occidental Petroleum's Piper Alpha rig in North Sea; 64 survivors. It is the world's worst offshore oil disaster.

November 10th, Saint John's, Newfoundland: Odyssey spilled 43 million gallons of oil.

March 24th, 1989, Prince William Sound, Alaska: tanker Exxon Valdez hit an undersea reef and spilled 10 million-plus gallons of oil into the water.

December 19th, off Las Palmas, the Canary Islands: explosion in Iranian supertanker, the Kharg-5, caused 19 million gallons of crude oil to spill into Atlantic Ocean about 400 mi north of Las Palmas, forming a 100-squaremile oil slick.

June 8th, 1990, off Galveston, Tex.: Mega Borg released 5.1 million gallons of oil some 60 nautical miles south-southeast of Galveston as a result of an explosion and subsequent fire in the pump room.

January 23rd-27th, 1991, southern Kuwait: during the Persian Gulf War, Iraq deliberately released 240-460 million gallons of crude oil into the Persian Gulf from tankers $10 \mathrm{mi}$ off Kuwait. Spill had little military significance. On January 27th, U.S. warplanes bombed pipe systems to stop the flow of oil.

April 11th, Genoa, Italy: Haven spilled 42 million gallons of oil in Genoa port.

May 28th, Angola: ABT Summer exploded and leaked 15-78 million gallons of oil off the coast of Angola. It's not clear how much sank or burned.

March 2nd, 1992, Fergana Valley, Uzbekistan: 88 million gallons of oil spilled from an oil well. 
August 10th, 1993, Tampa Bay, Fla.: three ships collided, the barge Bouchard B155, the freighter Balsa 37, and the barge Ocean 255. The Bouchard spilled an estimated 336,000 gallons of No. 6 fuel oil into Tampa Bay.

September 8th, 1994, Russia: dam built to contain oil burst and spilled oil into Kolva River tributary. U.S. Energy Department estimated spill at 2 million barrels. Russian state-owned oil company claimed spill was only 102,000 barrels.

February 15th, 1996, off Welsh coast: supertanker Sea Empress ran aground at port of Milford Haven, Wales, spewed out 70,000 tons of crude oil, and created a 25-mile slick.

December 12th, 1999, French Atlantic coast: Maltese-registered tanker Erika broke apart and sank off Britanny, spilling 3 million gallons of heavy oil into the sea.

January 18th, 2000, off Rio de Janeiro: ruptured pipeline owned by government oil company, Petrobras, spewed 343,200 gallons of heavy oil into Guanabara Bay.

November 28th, Mississippi River south of New Orleans: oil tanker Westchester lost power and ran aground near Port Sulphur, La., dumping 567,000 gallons of crude oil into lower Mississippi. Spill was largest in U.S. waters since Exxon Valdez disaster in March, 1989.

November 13th, 2002, Spain: Prestige suffered a damaged hull and was towed to sea and sank. Much of the 20 million gallons of oil remains underwater.

July 28th, 2003, Pakistan: The Tasman Spirit, a tanker, ran aground near the Karachi port, and eventually cracked into two pieces. One of its four oil tanks burst open, leaking 28,000 tons of crude oil into the sea.

December 7th, 2004, Unalaska, Aleutian Islands, Alaska: A major storm pushed the M/V Selendang Ayu up onto a rocky shore, breaking it in two. 337,000 gallons of oil were released, most of which was driven onto the shoreline of Makushin and Skan Bays.

August-September 2005, New Orleans, Louisiana: The Coast Guard estimated that more than 7 million gallons of oil were spilled during Hurricane Katrina from various sources, including pipelines, storage tanks and industrial plants.

June 19th, 2006, Calcasieu River, Louisiana: An estimated 71,000 barrels of waste oil were released from a tank at the CITGO Refinery on the Calcasieu River during a violent rain storm.

July 15th, Beirut, Lebanon: The Israeli navy bombs the Jieh coast power station, and between three million and ten million gallons of oil leaks into the sea, affecting nearly 100 miles of coastline. A coastal blockade, a result of the war, greatly hampers outside clean-up efforts. 
August 11th, Guimaras island, The Philippines: A tanker carrying 530,000 gallons of oil sinks off the coast of the Philippines, putting the country's fishing and tourism industries at great risk. The ship sinks in deep water, making it virtually unrecoverable, and it continues to emit oil into the ocean as other nations are called in to assist in the massive clean-up effort.

December 7th, 2007, South Korea: Oil spill causes environmental disaster, destroying beaches, coating birds and oysters with oil, and driving away tourists with its stench. The Hebei Spirit collides with a steel wire connecting a tug boat and barge five miles off South Korea's west coast, spilling 2.8 million gallons of crude oil. Seven thousand people are trying to clean up 12 miles of oil-coated coast.

July 25th, 2008, New Orleans, Louisiana: A 61-foot barge, carrying 419,000 gallons of heavy fuel, collides with a 600-foot tanker ship in the Mississippi River near New Orleans. Hundreds of thousands of gallons of fuel leak from the barge, causing a halt to all river traffic while cleanup efforts commence to limit the environmental fallout on local wildlife.

March 11th, 2009, Queensland, Australia: During Cyclone Hamish, unsecured cargo aboard the container ship MV Pacific Adventurer came loose on deck and caused the release of 52,000 gallons of heavy fuel and 620 tons of ammonium nitrate, a fertilizer, into the Coral Sea. About $60 \mathrm{~km}$ of the Sunshine Coast was covered in oil, prompting the closure of half the area's beaches.

January 23rd, 2010, Port Arthur, Texas: The oil tanker Eagle Otome and a barge collide in the Sabine-Neches Waterway, causing the release of about 462,000 gallons of crude oil. Environmental damage was minimal as about 46,000 gallons were recovered and 175,000 gallons were dispersed or evaporated, according to the U.S. Coast Guard.

April 24th, Gulf of Mexico: The Deepwater Horizon, a semisubmersible drilling rig, sank on April 22nd, after an April 20th explosion on the vessel. Eleven people died in the blast. When the rig sank, the riser-the 5,000-foot-long pipe that connects the wellhead to the rig-became detached and began leaking oil. In addition, U.S. Coast Guard investigators discovered a leak in the wellhead itself. As much as 60,000 barrels of oil per day were leaking into the water, threatening wildlife along the Louisiana Coast. Homeland Security Secretary Janet Napolitano declared it a "spill of national significance." BP (British Petroleum), which leased the Deepwater Horizon, is responsible for the cleanup, but the U.S. Navy supplied the company with resources to help contain the slick. Oil reached the Louisiana shore on April 30th, affected about 125 miles of coast. By early June, oil had also reached Florida, Alabama, and Mississippi. It is the largest oil spill in U.S. history.

It is well known that around $90 \%$ of world trade is carried out through international shipping (Shipping and World Trade, 2019). Through the above 
data, it is easily seen that the pollution problem caused by oil leakage is dangerous and may be a very high risk to today's environment. Therefore, it is very important to provide a clear and detailed legal framework to regulate the relationships that arise in the environmental field, especially for developing countries when they have to face between economic development and environmental protection (El-Ashry, 1993). This is extremely difficult for developing countries, and Vietnam is a good example.

The consequences of oil pollution and the losses they bring are not limited to the waters of specific countries or regions but often exceed the capabilities of each individual, organization, and sometimes the capabilities of a country. In order to mitigate and reduce damage, the international community needs to formulate legally binding common technical standards and provide human resources in the field of preventing oil pollution. Therefore, under the auspices of IMO, many international conventions on ship standards and crew standards have been established. These include: Convention on the Prevention of Marine Pollution from Ships MARPOL 73/78 (International Convention for the Prevention of Pollution from Ships (MARPOL), 2019); International Convention on the Intervention of International Oil Pollution Accidents in 1969 (Intervention) (International Convention Relating to Intervention on the High Seas in Cases of Oil Pollution Casualties, 1969, 1996); 1990 International Convention on Response to Oil Pollution (OPRC) (International Convention Relating to Intervention on the High Seas in Cases of Oil Pollution Casualties, 1969, 1996); Protocol on Response and Cooperation to Pollution by Hazardous and Toxic Substances (HNS Protocol) (Protocol on Preparedness, Response, and Co-operation to pollution Incidents by Hazardous and Noxious Substances, 2000 (OPRC-HNS Protocol), 2000).

Along with the International Oil Pollution and Cooperation Treaty, an international treaty to address damage caused by oil pollution from ships has also been established, namely: Civil Liability Convention 1969, 1992 Damage to oil pollution (CLC); International Convention on the Establishment of an International Oil Pollution Damage Compensation Fund; International Convention on Civil Liability and Compensation for the Transport of Dangerous and Toxic Substances by Sea (HNS), 1996; 2001 International Convention on Civil Liability for Compensation for Oil Pollution Damage. 
2. Main International Conventions on Preventing, Combating, and Compensating for Damage Caused by Offshore Oil Pollution

\subsection{Convention Group Proposes General Principles}

In this group of conventions, the most important international treaty is the International Convention on the Law of the Sea. The Convention was adopted in 1982 (UNLOCS 82) and entered into force on November 16th, 1994. As "Human Ocean Charter", the Convention stipulates comprehensive legal principles in the marine field. Although it does not elaborate on the issue of offshore oil pollution, the Convention contains basic provisions on the protection of the marine environment, which is the basis for the guidance of international legal provisions on environmental protection. This includes regulations to prevent oil pollution. In Article X192 of Article 192 on the protection and maintenance of the marine environment, the Convention reiterates a general rule: "States are obliged to protect and maintain the marine environment".

In addition, in accordance with the provisions of Article 225.3, in order to ensure prompt and appropriate compensation for all damage caused by marine pollution, the 1982 UNCLOS clearly states: "States need to cooperate for a certain period". This is to ensure the application and development of damage compensation in regard to the International law of liability for assessment, compensation, and dispute settlement, and where possible ensure appropriate standards and procedures for compensation such as the determination of compulsory insurance or compensation.

Countries have an obligation to cooperate with relevant countries and international organizations to the possible extent of eliminating the effects of pollution as well as preventing and minimizing pollution damage (Article 199 Contingency plans against pollution in Unlocs 82. Section 2. Global And Regional Cooperation, n.d.). The Convention also requires "global or regional cooperation in the formulation and drafting of rules and regulations and recommended international practices and procedures consistent with it. The Convention on the Protection and Maintenance of the Marine Environment also takes into account regional characteristics (Article 197 Cooperation on a global or regional basis in Unlocs 82. Section 2. Global And Regional Cooperation, N.D.). Therefore, countries are required to cooperate with each other directly or through intermediaries of competent international organizations to promote research, implement marine scientific research programs, and exchange information and general marine environmental data, especially marine environmental pollution data (Article 200 Studies, research programmes and exchange of information and data in Unlocs 82. Section 2.Global And Regional Cooperation, N.D.). 
The serious marine pollution problem is beyond the control of the country and requires close cooperation between countries in solving problems related to the marine environment and in construction. This is a common international legal framework for the protection of the marine environment. Prevention of marine pollution is now an urgent issue that needs to be addressed, not only for the benefit of a country, but also for the entire international community. By recognizing the importance of oceans to humans and the increasing pollution of oceans today, countries have and will continue to make greater efforts to protect and maintain the marine environment.

Therefore, according to the 1982 United Nations Convention on the Law of the Sea, the responsibility for paying for damages, including oil pollution and settlement plans, between polluting countries and organizations should be borne by the person responsible for the marine environment to countries.

\subsection{Convention Group for the Prevention and Control of Marine Oil Pollution}

(1) International Oil Pollution Prevention Convention (OILPOL 54)

On May 12, 1954, the first international conference on petroleum pollution was held in the United Kingdom. The meeting adopted the first convention on preventing marine pollution caused by oil, called OILPOL 54/69 (Nguyen Hong Thao, 2003). The purpose of the Convention is to control the activities of oil spill operations. As a result, tankers must dispose of oil in permitted areas, and all unloading and loading operations must be recorded in an oil diary. In 1962, 1969 and 1971, the Convention was revised and supplemented, and its focus was mainly on expanding the areas where oil spills are prohibited. The OILPOL 69 Amendment from the Torrey Canyon Great Ship Disaster revealed the weaknesses of OILPOL 54.

The 1971 amendment decided to expand the scope of application to small tankers, on the grounds that the small oil tanker usually causes less damage, especially in the event of collision and stranding. The oil and gas industry encountered strong opposition, so it never took effect (Vietnam Register, 2002).

A weakness of OILPOL 54 is that it does not specify the shipowner 's civil liability and the compensation mechanism for oil pollution damage. According to the provisions of this Convention, ships that violate the provisions of this Convention shall be dealt with in accordance with the laws of the country where the ship is registered. This happens if the ship does not comply with the regulations regarding the unloading and loading of oil within the permitted area. If pollution is caused within the permitted area, the damage will be compensated for in accordance with the laws of the ship's country of registration. 
In response to the practice of preventing oil pollution, the OILPOL 54 Convention has been replaced by the MARPOL 73/78 Convention. However, when MARPOL officially entered into force in 1983, the OILPOL 54 Convention continued to be applied in certain countries until those countries declared its abolition.

\section{(2) The 1969 International Convention on the Intervention of Offshore Oil Pollution Accidents (Intervention)}

The Convention stipulates that coastal states may take necessary measures at sea to prevent, limit or eliminate the harm of oil pollution or pollution threats to coastal areas. There is also a need to refuel after the marine accident. However, coastal states only allow refueling after accidents when necessary and after consulting with relevant organizations, especially in the flag state or in the country where the shipowner or cargo owner is located and where circumstances permit.

\section{(3) The 1973 International Convention for the Prevention of Marine Pollution} from Ships, revised and supplemented by the 1978 Protocol (MARPOL 73/78)

MARPOL 73/78 was adopted by the International Maritime Organization in 1973, revised and supplemented in 1978, and entered into force on January 2, 1983. The 73/78 Anti-Pollution Convention stipulates that accidents, including the accidental dumping of oil, hazardous substances, waste water, and waste in any form from water transport vehicles into the sea, are considered acts of Marine environmental pollution. At the same time, the ultimate goal of MAPOL $73 / 78$ is to eliminate all intentional marine pollution by controlling, domesticating, and reducing the discharge of harmful substances. MARPOL $73 / 78$ is also considered to be a comprehensive document which is the most effective tool for specifying all the contents of section 12 "Protection and Maintenance of the Marine Environment" of the 1982 United Nations Convention on the Law of the Sea.

Among the six annexes of MARPOL 73/78, Appendix I Regulations to Prevent Oil Pollution is the most mandatory and important. This annex sets new and stricter standards on ships to prevent the release of oil into the ocean. This annex requires some large tankers to have independent ballast water tanks and crude oil flushing systems. In addition, the annex requires that national ports establish adequate reception facilities to treat sludge and other wastes.

It can be said that since the birth of the 73/78 Anti-Pollution Convention, the amount of oil discharged into the ocean has greatly reduced. MARPOL 73/78 and its appendix have made important contributions to the protection of the marine environment, limiting activities that may cause high pollution. 
(4) International Petroleum Response and Cooperation Convention (OPRCLondon, November 30, 1990)

Like MARPOL, OPRC requires member states to establish an effective and timely response system in the event of a pollution incident. It stipulates that the agency is responsible for oil pollution prevention and response as well as sending oil pollution notices. The agency also has the right to seek help on its behalf or decide to seek help when requested. A national emergency plan must be developed and coordinated with other relevant agencies. The agency must also organize drills and conduct oil pollution emergency training.

\subsection{Convention Group on Civil Liability and Compensation for Damage Caused by Marine Oil Pollution}

(1) 1996 International Convention on Liability and Compensation for Loss of

Maritime Dangerous and Toxic Substances (HNS) (International Convention on Liability and Compensation for Damage in Connection with the Carriage of Hazardous and Noxious Substances by Sea (HNS), n.d.).

HNS provides a liability and compensation system based on a twolevel sanctions system such as the oil pollution sanction in the CLC and FUND conventions. The first and second compensation is the shipowner's responsibility. Two payments are made by the HNS fund which is provided by commodity stakeholders. The convention covers not only pollution but also other risks such as fires and explosions caused by dangerous and toxic substances. Compensation is not only for pollution damage in the territory and territorial waters, but also for the exclusive economic zone. The compensation limit is calculated based on the limits of the International Monetary Fund. The HNS Convention outlines the stipulates strict liabilities of shipowners, which is higher than the liability limit of the general liability system and mandatory insurance system and certificates.

The Convention does not apply to radioactive materials, coal, and other smaller cargos. However, it only applies to the following: Annex I, barrel oil listed in Annex I; Annex II, Annex II lists toxic liquid transport barrels, and substances classified in accordance with Article 3 (4) of Annex II of the Marlborough Convention; dangerous liquids specified in Chapter 17 of the IBC Code; dangerous and toxic substances specified in the IMDG Code; liquefied Liquor in 1983 Chapter 19 of the "Container Structure and Equipment Regulations" which mentions liquefied gas; liquids in barrels with a combustion temperature not exceeding $600^{\circ} \mathrm{C}$; and residues of these substances. According to the total tonnage of the ship, the first compensation limit will not exceed 100 million SDRs, while the maximum compensation limit specified in the HNS Convention is 250 million SDRs (International Convention on Liability and Compensation for Damage in Connection with the Carriage of Hazardous and Noxious Substances by Sea (HNS), n.d.). 
(2) The 1992 International Convention on Civil Liability for Oil Pollution Damage (CLC 1992)

CLC (International Convention on Civil Liability for Oil Pollution Damage) (INTERNATIONAL OIL POLLUTION COMPENSATION FUNDS 'Liability and compensation for oil pollution damage', n.d.)

The International Convention on Civil Liability for Oil Pollution Damage came into place in 1969 and is based on two standards that ensure safety at sea for those working and the entire environment. Subsequently, the Convention was amended twice in 1992 (entry into force on May 30, 1996) and in 2000 before entry into force on January 1, 2003. The Convention initially established a procedure for claiming compensation in the event of an oil pollution. The steps are as follows:

\section{Step 1- Collect Evidence and Assess Loss}

The 1992 CLC Convention did not specify the target for evidence collection and damage assessment. However, in practice, when the shipowner purchases insurance, the insurance agency is the competent authority to assess the loss and pay compensation to the complainant on this basis.

The Convention provided for the damage to the environment will be limited to restoring it regardless of the location of the spill and damage to the ship or outside the ship. The loss of income will not be compensated for regardless of the location of the oil spill or oil discharge. This is because of the damage caused outside the ship due to the pollution caused by the oil spill or the pollutants released from the ship. More so, except for loss of income, the compensation for the affected environment will be limited to restoration. This includes the actual cost of reasonable measures taken in the environment that has been or will be adopted.

Therefore, the cost of all measures (preventive measures) will also be included in the compensation package (Article 6, paragraph 6, of the 1992 CLC Convention).

\section{Step 2- Claim for Compensation Right to Appeal Liability Compensation}

The victim has the right to claim compensation. This includes individuals, organizations, associations, companies, private or public entities, and national and local governments.

\section{Party Responsible for Compensation}

The organization/individual is responsible for compensation, i.e., damage to the shipowner (according to Article 3, paragraph 1 of CLC 1992). However, under the conditions stipulated in Article 3, paragraphs 2 and 3 of 
the 1992 CLC Convention, the shipowner shall not bear any responsibility or exemption from liability.

If the owner proves the following facts, he will not be liable for pollution damage:

a) Caused by war, hostilities, civil war, violence or due to special, inevitable and irresistible natural phenomena.

b) Damage attributable entirely to the actions or omissions of third parties, or

c) If the damage is entirely caused by obstruction or misconduct caused by any government or agency responsible for maintaining beacons or assisted navigation functions. If the shipowner proves that the damage caused by the pollution is partly or wholly due to an act that deliberately caused damage to the person or due to his carelessness, the ship may be exempted from part or all of its liability to that person.

d) If the shipowner maintains insurance or financial security (participating in the transportation of more than 2,000 tons of bulk oil, the shipowner is required to participate in insurance or financial security).

\section{Determine the Scope of the Claim}

The injured party only gets compensated based on the shipowner's limited liability in the following three levels: (1) For ships with a tonnage of 5,000 tons or less, the liability limit is 4.51 million SDRs, which is approximately US \$ 5.78 million; (2) For ships with a tonnage exceeding 5,000 tons and 140,000 tons, an additional weight of 631 SDR/GT should be added per unit ton (US \$ 80); (3) For ships above 140,000 tons, the limit is 89.77 million SDR (special drawing rights) (\$11.5 million) (International Convention on Civil Liability for Oil Pollution Damage (CLC), n.d.).

\section{Identify the Solution and the Competent Authority}

When an incident causes pollution damage in the territory (including territorial sea or area) of one or more member states (including Article 2 of the CLC 1992 Convention) or when preventive measures have been taken to prevent or minimize the damage caused by pollution within the territories (including territorial seas and regions), compensation can only be claimed in the courts of a member country or state. The defendant must also receive appropriate notice of the complaint (Article IX of the 1992 CLC Convention). The procedures for claiming compensation include the following:

\section{The Plaintiff Filed a Complaint}

In the event of an oil pollution incident causing damage in its territory, territorial sea or exclusive economic zone, the claimant may file a complaint with the court of the party's state (Article IX.1). 


\section{The Defendant Set Up a Compensation Fund}

In order to limit the liability, the shipowner must establish a fund in the court or the competent authority of any member country that has the liability for an amount corresponding to the limit of liability. If compensation is required or no request is made, the fund shall be established in the court or competent authority of the Member State that may bring the trial (Article 5, paragraph 3).

If the shipowner has insurance or financial guarantee, the insurance or financial guarantor is the defendant in the lawsuit. The insurer or financial guarantor also has the right to set up a limited liability fund as a shipowner. If the shipowner is not entitled to the limitation of liability, the insurer or financial guarantor may limit his liability. In all cases, the defendant has the right to require the shipowner to participate in the litigation (Article 7, paragraph 8).

\section{Court proceedings}

\section{The Statute of Limitations for Filing a Lawsuit}

Within three years after the damage occurred, a statute of limitations should be filed in court. If an event, including a series of events, occurs, the limitation period for filing a lawsuit is 6 years from the date of the first occurrence (Article VIII of the 1992 CLC Convention).

\section{Identify the Courts that have the Power to Allocate Funds}

After the defendant establishes the fund, the court of the country that established the fund will be the only court that has the power to decide all matters related to the distribution of the fund (Article IX, Item 3 of the 1992 CLC Convention).

\section{Take Temporary Emergency Measures}

Only when the defendant fails to establish a fund after the damage is done, in accordance with Article 5 of the Convention, can the court take temporary emergency measures.

If the shipowner has established a fund, then: (a) the claimant shall not exercise any rights against the shipowner's other properties in such claims, and (b) the court or any competent state party has the power to order the release of the ship or any of the shipowner's other previously detained properties to claim compensation and release any monetary guarantee or other guarantee (Article VI, paragraph 1). 


\section{Recognize and Enforce Court Decisions}

Any decision made by the competent court that is enforceable in the country where the judgment is located is no longer subject to any other form of joint appeal and should be recognized in another Member State. However, this is subject to change if: (a) a court decision is made through fraud, or (b) the defendant has not received proper notice and has no equal opportunity to defend (Article 10). These judgments will take effect in each state party as soon as the state party has completed the required procedures.

\section{(3) International Convention on the Establishment of the International Oil Pollution Damage Compensation Fund in 1992 (FUND 1992)}

The 1992 Fund is a supplement to the 1992 CLC Convention, which aims to establish a compensation system because the compensation provided by the 1992 CLC is incomplete. The International Oil Pollution Compensation Fund 1992 (IOPC 1992) entered into force on May 30, 1996, in accordance with the 1996 Fund Convention. The 1992 Foundation is a global intergovernmental organization whose operations are compensated in accordance with the Fund Foundation's 1992 agreement. The process of claiming compensation under FUND in 1992 is as follows:

\section{Step 1: The Injured Party makes a Complaint}

Subject Claims Compensation

Anyone who has suffered a loss in a State party to the Convention has the right to file a claim and claim damages (Article 4 of the 1992 Fund Convention). Claimants for damages can be individuals, organizations, associations, companies, private or public entities, including national and local governments. If a group of plaintiffs suffer the same damage, they may seek more favorable conditions to cooperate with each other to file a complaint (2008 Claims Manual, Section 2.1.2).

Who made a Complaint to the Victim?

When damage occurred in 1992, the FUND Foundation cooperated with the shipowner's insurer and the Maritime Guarantee and Insurance Association ( $\mathrm{P} \& \mathrm{I}$ club) and guaranteed the ship's third-party liability, including responsibility for damage caused by oil pollution.

When the incident caused a large number of complaints, the FUND 1992 Foundation and the P \& I Club jointly set up a local complaint office to handle complaints more easily. This means that any plaintiff would have to complain to the office (Claims Manual. As adopted by the 1992 Fund Assembly in April 1998 and amended, most recently in April 2018, by the 1992 Fund Administrative Council, n.d.) An example is given in the case of "Hebei Spirit" in South Korea. In January 2008, when receiving a large number of complaints, FUND and Skuld Club (P \& I Club) opened the 
Complaint Office (Hebei Spirit Center) to assist the plaintiff in filing a claim in Seoul (International Convention on the Establishment of an Oil Pollution Compensation Fund, Guidelines for Claims in 2008 (IOPC Fund, 2008 Claims Manual), n.d.).

\section{How to File a Complaint from the Plaintiff}

Complaints should be in writing (fax or e-mail is also possible). If possible, $\mathrm{P} \& \mathrm{I}$ and/or FUND will issue a complaint form to assist the plaintiff in filing a complaint.

Complaints must be clear and provide complete information. Each item of the complaint must be supported by invoices, documents or other relevant documents provided such as working documents, explanatory documents, calculation results, and pictures. The plaintiff is obliged to provide sufficient evidence to support his claim (International Convention on the Establishment of an Oil Pollution Compensation Fund, Guidelines for Claims in 2008 (IOPC Fund, 2008 Claims Manual), n.d.).

\section{Content in the Claimant's Complaint}

Each complaint should include the following basic information: (1) the name and address of the claimant and any representative; (2) identify the ship involved in the incident; (3) if the claimant knows the date, location, and special circumstances of the incident, this should be provided, unless this information can be used by the 1992 FUND Foundation; (4) types of pollution damage suffered; (5) payment for claims.

\section{When Should I Complain?}

After the damage occurred, the plaintiff should file an appeal as soon as possible. If a formal complaint cannot be filed as soon as possible after the incident, the 1992 FUND Foundation will conduct an assessment and notify the plaintiff as soon as possible of the intention to file a complaint at the time of the incident. The plaintiff will provide the above details if possible.

Furthermore, the plaintiffs will estimate the loss of their right to compensation under the 1992 Fund Convention unless they file a lawsuit or give notice to the fund within 3 years from the date of the damage. Notice to file a lawsuit against the shipowner or shipowner's insurer according to the 1992 fund of the court is possible within three years (UNITED NATIONS CONFERENCE ON TRADE AND DEVELOPMENT. Liability and Compensation for Ship-Source Oil Pollution: An Overview of the International Legal Framework for Oil Pollution Damage from Tankers, n.d.). 


\section{Step 2: Assess Damage}

The authorities are in charge of evaluating the damage with the IOPC FUND 1992. Although the 1992 FUND Convention does not have specific provisions on damage assessment, according to FUND 's guidance documents, organizations that can participate in damage assessment include INTERTANKO, OGP, ICS, IOPCF, ITOPF, UNNEP, P \& I clubs, etc. When the incident occurs, FUND 1992 works with the shipowner's insurance company to appoint experts to guide the cleaning process. Researchers also check for the compatibility of the technology and conduct independent assessment of loss and damage.

\section{The Types of Damages and Methods of Assessing Damages Based on IOPC FUND 1992}

The 1992 Fund Convention provides for pollution compensation, which is discussed in Article 1, paragraph 2:

"Losses that occur outside the ship are due to oil spills or pollutants released from the ship. No matter where the oil leaks or releases, compensation will be paid. In addition to such loss of income, compensation for the affected environment will be limited to the actual cost of the measures taken to restore the environment, as well as the cost of taking preventive measures and the loss or damage caused by these measures.

Shipowners voluntarily make reasonable expenditures or reasonable sacrifices to prevent or limit damage caused by pollution.

More specifically, in FUND's Complaint Guide, the losses considered and assessed include: the cost of cleaning and pollution prevention measures; property losses; pure economic losses; economic losses in fisheries, marine animal, plant breeding, and fishing areas; economic losses in tourist areas; damage and environmental and oil spill lessons; and use by consultants (Zhang, 2008).

In each type of damage compensation, FUND provides guidelines for the scope of compensation in the plaintiff 's claim.

\section{Notify the Plaintiff of the Damage Assessment Result}

Once the fund and the P \& I Association make a decision on the complaint, the plaintiff is usually notified in writing to explain the basis of the evaluation. If the plaintiff decides to accept the claim, the plaintiff will be required to sign the receipt for the payment. If the plaintiff does not agree with the evaluation of the complaint, the plaintiff may provide additional information and demand higher value. 


\section{Step 3: Decide on Compensation}

The Ability to Determine Compensation

In 1992, FUND usually cooperated with the shipowner's insurance company and appointed experts to independently guide the process of cleaning, investigating, and evaluating damage. Although the foundation and P \& I relied on experts to assist in evaluating complaints in 1992, the decision to accept or reject specific complaints is still up to the federation and the foundation. If it is not possible to agree on an evaluation complaint, the plaintiff has the right to submit his complaint to the competent court of the country or region where the damage was caused.

\section{Compensation Limit}

The injured party is compensated by the FUND foundation 1992 only within the scope of the fund's liability. More specifically, this involves events that occurred on or after November 1, 2003, and are over 203 million SDRs, regardless of the size of the ship (including the amount paid in accordance with the 1992 Liability Convention). Also, this includes events that occurred before November 1, 2003, that have amounted to SDR 135 million (including the amount paid under the 1992 Liability Convention).

\section{Step 4: File a Lawsuit in the Competent Court}

Terms of Limitation for Filing Claims

The right to claim is only valid for three years from the date of the damage in the case of a claim or notification under Article 7, paragraph 6, of the Convention. If a complaint is filed six years after the incident caused damage, the complaint will not be considered (Article 6 of the 1992 Fund Convention).

\section{Identify the Competent Court}

The general principle for determining jurisdiction in oil pollution cases is "the competent court of the country where the damage occurred". However, when a claim for compensation for oil pollution damage is filed with the competent court under Article IX of the 1992 Liability Convention, the court shall be directed against the shipowner or the shipowner's guarantor, and the court shall be responsible if any claim has sole jurisdiction.

If claims for oil pollution compensation under the 1992 Liability Convention have been submitted to the 1992 Liability Convention member courts and not the 1992 Fund Convention member states, any claim against the Fund under the Convention shall be at the discretion of the complainant. Thereafter, it shall be submitted to the court in the country where the fund's headquarters is located or any court in a country. The parties to this Convention have jurisdiction over Article 9 of the 1992 Liability Convention. 


\section{Recognize and Enforce the Court's Judgment}

On the premise of making any decision on the appropriation, any judgment on the fund made by the competent court that is valid in the country of review and does not need to be appealed should be considered. Such actions shall be effective and enforceable in each State Party.

(4) The 2001 International Convention on Civil Liability and Compensation, covering oil pollution from ship fuel depots (Bunker, 2001)(Civil liability for oil pollution damage: Bunkers Convention. It authorises EU countries to sign, ratify or accede to the 2001 International Convention on Civil Liability for Bunker Oil Pollution Damage (Bunkers Convention, 2001)

From January 1, 2001, to September 30, 2002, the Bunker 2001 Convention was opened for ratification and acceptance. The scope of this Convention applies to any type of hydrocarbon mineral oil used or intended to be used in the operation or propulsion of ships. This also includes lubricants and its residues causing pollution damage in the territory, not exceeding 200 nautical miles from the baseline, the territorial sea, Tablet PC in an exclusive economic zone or a contiguous zone (if there is no exclusive economic zone and is determined in accordance with international law). The Convention stipulates that ships with a gross tonnage of 1,000 tons gross or more must have insurance certificates or other financial guarantees issued by member states. The Convention is a supplement to CLC and FC systems, and it covers marine pollution caused by other oils which are not covered by CLC and FC. Reports show that currently 52 countries have joined the Convention, and the fleet capacity accounts for approximately $84.57 \%$ of the total capacity of the world trade fleet. The fact that Vietnam officially acceded to the Bunker Convention is important. This has not only helped Vietnam have a sufficient legal basis to resolve oil pollution claims, but it has also enhanced Vietnam 's reputation (Dang, 2012).

\section{Vietnam laws on Prevention and Remediation for Marine}

In the process of innovation and international economic integration, global issues and environmental pollution have become an important survival issue for Vietnam. Since Vietnam is a country that exports crude oil and imports finished products, it is located at an international crossroads to the ocean. Therefore, the problem of oil pollution in Vietnam's waters to the ocean is an important problem that needs to be solved. Vietnam has formulated and completed a set of laws and regulations to prevent and overcome marine pollution. Vietnam's general and special legal documents also recognize this (PVN 'How the proper understanding of the petroleum market', n.d.).

The 2013 Constitution of the Socialist Republic of Vietnam stipulates the highest legal and political ideology that everyone has the right to live in a 
clean and meaningful environment (The National Assembly, 2013). There is also provision for Environmental Protection in the constitution (Article 43) which states that; organizations and individuals that cause environmental pollution, consume natural resources, and reduce biodiversity must be strictly dealt with and be held responsible for overcoming and compensating for damage. These are important provisions recorded in the Constitution and they form the basis of environmental protection laws and regulations.

In 2014, the Environmental Protection Law (Pursuant to the Constitution of the Socialist Republic of Vietnam, 2014) (Pursuant to the Constitution of the Socialist Republic of Vietnam, 2015) was brought into effect, which established a chapter specifically on "Environmental Protection of Oceans and Islands", and it includes provisions on principles of marine environmental protection, rational use of marine resources, and pollution control. When compared with the provisions of the 2005 Environmental Protection Law (marine environmental protection is defined as one), the provisions of the 2014 Environmental Protection Law on marine environmental protection clearly shows the importance of control, prevention, and overcoming. Incidents that pollute the marine environment include incidents that involve contaminated water with oil and other wastes. When exploring, developing, transporting, storing and processing oil and natural gas, all organizations and individuals must apply appropriate technologies, fully implement the necessary environmental protection measures, and formulate preventive measures to avoid oil leakage.

Regarding pollution remediation, Vietnam's environmental law recognizes the following principle: "Polluters must compensate for losses and take remedial measures". This special principle is based on the general legal principle which states that: "If damage is caused, compensation must be made".

Vietnam's Maritime Law 2015 (Pursuant to the Constitution of the Socialist Republic of Vietnam, 2015) confirms that the protection, renewal, and sustainable development of the marine environment related to economic guarantees are an important principle, and it is reflected in the 6 articles of the law on marine environmental protection. The Maritime Law has many provisions, which specifies the provisions of the MARPOL 73/78 Convention on pollution prevention certificates; inspection, control and prohibition of ships and ports that are not capable of preventing pollution; Ship port; and compulsory civil liability insurance obligation for environmental pollution caused by oil tankers (Article 300). The law specifically stipulates that marine pollution activities are not limited to civil liability. When ships cause oil spills, civil liability will be investigated in accordance with the Convention. If the vessel that caused the oil leakage is an oil tanker, and the oil leaked is heavy oil that is difficult to decompose, then civil liability is assumed for damage 
caused by oil pollution (CLC 69/72). The Maritime Law also emphasizes that environmental complaints are the basis for the right to arrest ships (Chapter VI, Chapter II, Article 139) to ensure the management and timely handling of pollution-causing activities.

The 2013 Vietnam Petroleum Law (Pursuant to the Law on Government Organization dated December 25, 2013) stipulates that entities involved in oil and gas activities must use advanced technologies and comply with the provisions of Vietnamese law on the protection of natural resources, environmental protection, and personal and property safety (Article 4). In addition, the owner must have environmental protection recommendations and measures (Article 5). These entities are legally responsible for damage caused to people, property, and the environment. In particular, the status quo must be restored before any activities resume that directly or indirectly affect the environment and cause damage.

Vietnam's 2015 Civil Code (Vietnam, 2015) stipulates that individuals, legal entities, and other entities that pollute the environment causing damage must compensate for the damage according to regulations, including cases that cause environmental pollution. Thus, there is no error in this field. If the owner wishes to waive such ownership that may pollute the environment, such waiver must also abide by the law (Article 249). The owner must abide by the Environmental Protection Law when using, saving,or giving up property, stop acts that cause pollution, and take appropriate measures. Therefore, in regard to the pollution of the marine environment, in the case of the use of dangerous sources (including damage caused by oil), the liability for compensation shall be The Vietnam Criminal Code 2015 which has more specific provisions on environmental crime. Specifically, Chapter 19 makes 12 provisions on environmental crimes, including environmental pollution crimes (Article 235) and crimes that violate regulations on prevention, response, and overcoming environmental events (Article 237). According to Article 237, depending on the seriousness of violations of prevention, response and overcoming environmental incidents, individuals and legal persons can be fined $50 \%$, which can be between one million or even ten billion Vietnamese dong. The term of imprisonment ranges from 6 months to a maximum of 7 years for individuals and legal entities (LÊ VĂN SUA, 2015). The imprisonment ranges from 5 to 10 years, depending on the degree of damage and the nature of the illegal act. Other punishments include prohibiting holding positions, and prohibiting practices related to the environment and environmental protection. A new feature of the provisions on environmental pollution in the 2015 Criminal Code states that the document provides quantitative figures to determine the extent of violations and the corresponding penalties (Article 235). Such regulations will ensure the specificity and clarity in determining the pollution level, and thus determine the penalty framework suitable for the 
subject of environmental pollution. Therefore, Vietnam's legislative point of view has shown that in accordance with the provisions of the International Environmental Protection Law, Vietnam has made progress in ensuring severe penalties for acts that pollute nature and the legal person's environment in Vietnam.

The "Vietnamese Coast Guard Regulations of 2008" stipulates that one of the important tasks of this force is to protect the country 's natural resources and environment, as well as to prevent and treat it. Therefore, environmental pollution (including oil pollution from the oceans within the jurisdiction of Vietnam) mitigation measures include a Vietnamese law and the International exclusive economic zone membership.

In addition to the above laws, the prevention and overcoming of general marine pollution, especially the oil pollution of ships, are also subject to different jurisdictions of the 2003 Fisheries Law, the 2012 Vietnam Ocean Law, and cargo. This includes a series of other decrees, notices, and related directives.

From a legislative point of view, it can be asserted that Vietnam has a system of legal regulations on the prevention and remediation of marine pollution. However, the regulations on umbrella protection and remediation are is of particular concern because marine pollution from ships is the most dangerous. It must be emphasized that the rules and regulations are recognized in Vietnam's specific laws, rather than concentrated in specific legal documents, and their implementation is based on laws and regulations. There are accompanying instructions to ensure effective implementation and compliance with the law. In the actual application process, the results are encouraging. Nonetheless, there are certain shortcomings and deficiencies.

In the case of dumping waste oil into the Da River water source, the People's Court of Hoa Binh City sentenced Ly Dinh Vu to 5 years in prison, Hoang Van Tham 4 years, and Nguyen Chuong Dai 3 years and six months in prison. At the trial as well as at the investigation agency, the three subjects, i.e., Ly Dinh Vu (born 1982), Nguyen Chuong Dai (residing in Thuan Thanh district (Bac Ninh province) and was born in 1994), and Hoang Van Tham (born in the year 1994 and residing in Van Quan district (Lang Son province) sincerely confessed to the criminal acts. After comprehensively reviewing the case content, based on the nature, severity and criminal acts of each defendant, the Trial Panel of the People's Court of Hoa Binh City sentenced Ly Dinh Vu to 5 years in prison. On the other hand, Hoang Van Tham was detained for 4 years in prison while Nguyen Chuong Dai spent 3 years and six months in prison for the same crime of "causing environmental pollution". Regarding civil liability, Da river Clean Water Investment Joint Stock Company requested the defendants and CTH Ceramics Joint Stock Company to reimburse the costs of incident response and handling oil pollution into the 
water source with a total amount of more than 5.6 billion Vietnam Dong (TTXVN, n.d.) However, the process of investigation and additional investigation at the request of the Court has not clarified the level of damage. Considering that compensation for damage and reimbursement does not affect the resolution of the case, it needs to be separated for settlement by another civil case so that the Trial Panel does not mention settlement. According to the case content, on the morning of October 9, 2019, the staff of Song Da Clean Water Investment Joint Stock Company discovered a streak of the oil slick, stinking on the stream leading water to Dam Bai lake, and it poured into the factory. The company reported to the police about the incident to find the source of the dumping. Through the investigation, Hoa Binh Provincial Police determined that, in early October 2019, Ly Dinh Vu and Nguyen Thi Huyen Trang had exchanged telephone conversations about Vu's treatment of waste oil for CTH Ceramics Joint Stock Company for 1,000 VND/liter. On October 6, 2019, Vu directed Nguyen Chuong Dai and Hoang Van Tham to drive with ten plastic containers of 1,000 liters/barrel from Thuan Thanh (Bac Ninh) to CTH Ceramics Joint Stock Company in Phu Tho town (Phu Tho province) to absorb waste oil with a total weight of $8,830 \mathrm{~kg}$. After that, Dai and Tham transported the oil to Van Lam district (Hung Yen) for Vu to find a place to dump the waste. At 4:00 on October 8, 2019, Ly Dinh Vu called Nguyen Chuong Dai and Hoang Van Tham to drive the above waste oil to the Phuc Tien - Phu Minh inter-commune road to dump. In the process of sampling, investigation, and inspection conclusions of the authorities, it was indicated that in the waste samples collected at the dumping site, the most dangerous ingredient was benzene (PV, n.d.).

Therefore, it is necessary to perfect the legal system of marine environmental protection in Vietnam. In addition, the law allows the use of a non-contractual compensation system to investigate liability for environmental pollution caused by emissions, discharges, or oil spills.

\section{Some Comments and Suggestions on Joining the International Convention on Preventing, Combating, and Compensating the Damage Caused by Oil Pollution in Vietnam's Seas}

With the joint efforts of countries and international organizations, a series of international treaties on marine environmental protection, especially the prevention and control of oil pollution damage was born. This was done in order to establish an international legal framework for global marine environmental protection activities. The above-mentioned international conventions elaborate on human environmental protection policies in the field of oil pollution (25 years of implementation of UNCLOS in Vietnam, n.d.):

(1) The ocean is a common resource for mankind. Therefore, protecting the marine environment is the responsibility of all mankind and the 
responsibility of the country and users as well. This international convention clearly stipulates this principle as seen through UNLOCS 82, the Convention on the Prevention of Marine Pollution from Ships (MARPOL 73/78), the Convention on the Limitation of Shipowners' Civil Rights, and the establishment of an international compensation fund for damage caused by ship pollution.

(2) Shipowners' Rights Protection Policy: This policy is reflected in the limitation of shipowners' civil liability for environmental damage. In other words, the shipowner is only liable for compensation for pollution damage caused by the ship based on the tonnage limit of the ship. The 1992 CLC Convention, the 1996 HNS Convention, and the 2001 Bunker Convention all clearly show this.

(3) The policy states that cargo ship is responsible for damage caused by oil pollution. Cargo transported by sea is one of the main sources of marine pollution. Therefore, this means that the owner of cargo transported by sea must also bear all the liability. This policy supports the shipowner's protection policy, and it is clearly stipulated in the FUND Convention that the convention is a user of oil. In other words, oil importers are jointly responsible for damage to marine pollution because there is oil on board.

(4) More Preventative Policy: MARPOL 73/78 Convention expresses this policy very clearly. The Convention outlines the measures taken to prevent marine pollution from ships, including the design and equipment requirements for ships. Furthermore, the owner and captain of the ship are responsible for the implementation of waste discharge regulations arising from the ship's activities. Ships and ports are responsible for organizing the reception of these wastes through the shore waste reception system.

(5) A Policy to Protect the Rights of Marine Users: This policy is reflected in the compensation regulations for marine users who have suffered damage due to marine pollution. Damage that can be compensated includes not only direct damage, but also indirect damage. In particular, the compensation costs include not only the damage to the marine products caused by cleaning up the marine environment and the costs immediately after pollution, but also the damage caused by the effects of post-pollution. Loss of income from tourism, hotels, fisheries, and aquaculture decreased. Hence, these indirect damages may have consequences in the next few years such as the absence of tourists, fisheries, etc.

It can be seen that international conventions have established a complete international legal framework to protect the marine environment as a whole, as well as to prevent and respond to oil pollution incidents. From the perspective of a comprehensive assessment of the international convention system for oil pollution, and based on a series of conventions (1) that Vietnam has signed and acceded to, it can be said that Vietnam is still outside many 
conventions on oil pollution. In order to create the necessary legal foundation, Vietnam must urgently promote participation in other important international oil pollution treaties in the near future such as the Convention on Readiness for International Cooperation and Response (Petroleum Pollution (OPRC, 1990), International Convention on Intervention in Oil Pollution Accidents at Sea (1969), Protocol on Response and Cooperation on Accidental Pollution by Hazardous and Toxic Substances (HNS Protocol 2000), and International Convention on Civil Liability and Compensation for the Transport of Dangerous and Toxic Substances by Sea (HNS 1996)). Vietnam needs to develop a road map to accede to the 1992 FUND Convention as a way to conduct the legal basis for claims for damage caused by pollution. Therefore, joining the 1992 fund will bring the following benefits to Vietnam:

After becoming a party to the 1992 FUND Convention, any tanker in any country, whether or not it is a part the FUND Convention, only needs to pollute the waters of Vietnam, and Vietnam will have the right to appeal. The claim from IOPC 1992 is particularly meaningful for Vietnam. As predicted in the near future, the number of tankers entering and leaving Vietnam's waters will rapidly increase mined crude products and imported petroleum products from Vietnamese water. In addition, due to the status of the Vietnam Sea on international maritime routes and the demand for energy products from the North and Southeast Asian economies, the number of foreign vessels going to Vietnam is increasing. This means that the Vietnamese waters are in danger of being polluted by oil. Oil pollution on board often causes severe damage. If it is not a member of the 1992 Fund, Vietnam will not be compensated by the 1992 International IOPC.

According to the 1992 FUND Convention, crude oil importers must pay the IOPC 1992 annual dues based on the amount of oil imported and the fees that IOPC 1992 must pay that year. This means that when Vietnam becomes a party to the 1992 FUND Convention, Vietnam must fulfill its annual obligation to pay the IOPC 1992 like other members. However, Vietnam is still an exporter and has not yet contributed to the 1992 Fund Convention. In the future, they have to make their own contribution to the fund so that oil imported from Vietnam can be relied upon according to forecasts. Vietnam's oil imports are small compared to their exports, especially the amount of sustainable oil (crude oil, heavy oil) in the oil list provided by the 1992 CLC Convention. Vietnam will benefit from paying into the IOPC 1992 fund because the cost will be small, but in return, they will receive full sponsorship from IOPC 1992.

Petroleum importers and organizations will donate directly to IOPC 1992 instead of donating to IOPC 1992 through the Vietnamese government. Therefore, the Vietnamese government does not have to face any difficulties in collecting and paying IOPC 1992. The Vietnamese government is only 
focused on ensuring that organizations and individuals importing oil fulfill their obligations to IOPC. The management of Vietnamese's resources will improve through their participation in these international agreements.

As a member of the 1992 FUND Convention, other member states will consider the effective decisions and judgments of the competent Vietnamese court on compensation for damage caused by oil pollution from ships.

In addition, joining the 1992 Fund helps to establish and improve regulations on compensation for the marine environment in accordance with regional and international standards. It also creates a legal basis for promoting international cooperation to protect the marine environment to meet integration requirements.

\section{Conclusion}

With the development of the marine economy, Vietnam faces the risk of serious marine pollution and degradation due to oil spills. At the same time, Vietnam is still outside many international conventions related to environmental protection and shipping activities (including activities of ships, ports, shipbuilding and repair facilities, etc.). They are also outside many international treaties to prevent oil pollution and oil spills response. Delaying accession to these international conventions not only reduces the competitiveness of Vietnamese flag ship registration, but it also negatively affects Vietnam's maritime safety and environment.

Hence, by singing and acceding to many treaties, Vietnam puts into effect both effective and safe oil pollution protection measures and ensures national rights and interests. In the case of protecting the marine environment and preventing and responding to oil spills throughout the sea, Vietnam needs to implement simultaneous solutions, including solutions to establish and improve the legal system for compensation. Damage caused by oil pollution according to specific routes suitable for Vietnam's national conditions, and in compliance with international regulations and practices, needs to be compensated. With the determination of the political system and the efforts of relevant agencies, organizations and individuals, it is hoped that Vietnam will not deviate from many international environmental protection conventions in the near future. Offshore schools to prevent oil pollution are established for a comprehensive, scientific, and modern environmental protection legal system. Thus, this prevents, sanctions, and demands compensation for oil pollution damage. 


\section{References:}

1. 25 years of implementation of UNCLOS in Vietnam. (n.d.). Retrieved from https://www.nhandan.com.vn/chinhtri/item/42438102-changduong-25-nam-thuc-thi-unclos-cua-viet-nam.html

2. Article 197 Cooperation on a global or regional basis in Unlocs 82. Section 2. Global And Regional Cooperation. (n.d.). Retrieved from https://www.un.org/depts/los/convention_agreements/texts/unclos/un clos_e.pdf

3. Article 199 Contingency plans against pollution in Unlocs 82. Section 2. Global And Regional Cooperation. (n.d.). Retrieved from https://www.un.org/depts/los/convention_agreements/texts/unclos/un clos_e.pdf

4. Article 200 Studies, research programmes and exchange of information and data in Unlocs 82. Section 2.Global And Regional Cooperation. (N.D.). Retrieved from https://www.un.org/depts/los/convention_agreements/texts/unclos/un clos_e.pdf

5. Civil liability for oil pollution damage: Bunkers Convention. It authorises EU countries to sign, ratify or accede to the 2001 International Convention on Civil Liability for Bunker Oil Pollution Damage (Bunkers Convention). (2001). Retrieved from https://eurlex.europa.eu/legal-content/EN/TXT/?uri=LEGISSUM\%3A124090

6. Claims Manual. As adopted by the 1992 Fund Assembly in April 1998 and amended, most recently in April 2018, by the 1992 Fund Administrative Council. (n.d.). Retrieved from https://iopcfunds.org/wp-content/uploads/2018/12/2019-ClaimsManual_e-1.pdf

7. Dang, M. H. (2012). Japanese law on prevention, combat and compensation for damages caused by oil pollution at sea-Lessons learned for Vietnam.". VNU Journal of Science: Economics and Business 28.1.

8. El-Ashry, M. T. (1993). Balancing economic development with environmental protection in developing and lesser developed countries. Air \& Waste, 43(1), 18-24.

9. International Convention for the Prevention of Pollution from Ships (MARPOL). (2019). Retrieved from http://www.imo.org/en/About/Conventions/ListOfConventions/Pages /International-Convention-for-the-Prevention-of-Pollution-fromShips-(MARPOL).aspx \%0A

10. International Convention on Civil Liability for Oil Pollution Damage (CLC). (n.d.). Retrieved from http://www.imo.org/es/About/Conventions/ListOfConventions/Pagin 
as/International-Convention-on-Civil-Liability-for-Oil-PollutionDamage-(CLC).aspx

11. International Convention on Liability and Compensation for Damage in Connection with the Carriage of Hazardous and Noxious Substances by Sea (HNS). (n.d.). Retrieved from http://www.imo.org/en/About/Conventions/ListOfConventions/Pages /International-Convention-on-Liability-and-Compensation-forDamage-in-Connection-with-the-Carriage-of-Hazardous-andNoxious-.aspx

12. International Convention on the Establishment of an Oil Pollution Compensation Fund", Guidelines for Claims in 2008 (IOPC Fund, 2008 Claims Manual),. (n.d.).

13. International Convention Relating to Intervention on the High Seas in Cases of Oil Pollution Casualties, 1969 (1996). Retrieved from http://www.imo.org/en/About/Conventions/ListOfConventions/Pages /International-Convention-Relating-to-Intervention-on-the-HighSeas-in-Cases-of-Oil-Pollution-Casualties.aspx

14. International Oil Pollution Compensation Funds. "Liability and compensation for oil pollution damage". (n.d.). Retrieved from https://iopcfunds.org/wp-content/uploads/2018/06/Text-ofConventions_e.pdf

15. Lê Văn Sua (2015). Principle of Compensation For Foreign Damage Outside the Contract by the Civil Code 2015. Retrieved from https://thongtinphapluatdansu.edu.vn/2018/11/19/nguyen-tac-boithuong-thiet-hai-ngoai-hop-dong-theo-bo-luat-dan-su-nam-2015/

16. Nguyen Hong Thao (2003). "Marine Environmental Pollution in Vietnam, Law and Practice”.

17. Protocol on Preparedness, Response and Co-operation to pollution Incidents by Hazardous and Noxious Substances, 2000 (OPRC-HNS Protocol)". (2000). Retrieved from http://www.imo.org/en/About/Conventions/ListOfConventions/Pages /Protocol-on-Preparedness,-Response-and-Co-operation-to-pollutionIncidents-by-Hazardous-and-Noxious-Substances-(OPRC-HNSPr.aspx \%0A

18. Pursuant to the Constitution of the Socialist Republic of Vietnam. Law On Environmental Protection 2014. , (2014).

19. Pursuant to the Constitution of the Socialist Republic of Vietnam. Vietnam Maritime Code 2015. , (2015).

20. Pursuant to the Law on Government Organization dated December 25, 2001. Decree1. On the Model Petroleum Production Sharing Contract 2013. , (2013). 
21. PV. (n.d.). 150 months of imprisonment for 3 subjects who stole waste oil into the water supply for Hanoi. Retrieved from http://baohoabinh.com.vn/217/144119/150thang-tu-cho-3-doi-tuongdo-trom-dau-thai-vao-dau-nguon-cap-nuoc-cho-thanh-pho-HaNoi.htm

22. PVN "How the proper understanding of the petroleum market". (n.d.). Retrieved from http://www.pvn.vn/Pages/detail.aspx?NewsID=59e0d1c9-93ae-432c9153-817d8edf7e99

23. "Shipping and World Trade". (2019). Retrieved from http://www.icsshipping.org/shipping-facts/shipping-and-world-trade

24. Staff, T. I. (2017). "Oil Spills and Disasters Timeline." Retrieved from https://www.infoplease.com/world/disasters/man-made/oil-spills-anddisasters-timeline

25. The National Assembly. (2013). The Constitution Of The Socialist Republic Of Vietnam (2013) Unofficial Translation from Vietnamese by International IDEA. The Socialist Republic of Vietnam. Retrieved from

http://www.constitutionnet.org/sites/default/files/tranlation_of_vietna ms_new_constitution_enuk_2.pdf

26. TTXVN. (n.d.). Three people "poisoning" the clean water source of The River was sentenced to prison. Retrieved from https://vtv.vn/phapluat/3-doi-tuong-dau-doc-nguon-nuoc-sach-song-da-linh-an-tu20200731165850791.htm

27. United Nations Conference On Trade And Development. Liability and Compensation for Ship-Source Oil Pollution: An Overview of the International Legal Framework for Oil Pollution Damage from Tankers. (n.d.). Retrieved from https://unctad.org/en/PublicationsLibrary/dtltlb20114_en.pdf \%0A

28. Vietnam, P. (2015). To the C. of the S. R. of. Civil Code 2015.

29. Vietnam Register (2002). "MARPOL 73/78."

30. Zhang, F. (2008). U.S. Patent No. 7,458,386. Washington, DC: U.S. Patent and Trademark Office.

31. Dien, N. B. (2011). Overview of international legal regulations on prevention, protection, and compensation of oil pollution on the sea. VNU Journal of Science: Legal Studies, 27, 30-41 